\title{
Enhancing the $\mathrm{NaCl}$ Tolerance Potential of Wheat on Root Morphology and Osmoregulation Substance by Exogenous Application of Bacillus subtilis QM3
}

\author{
Ruiqing Liu, Caifang Wen, Zhifang Zhao, Guang Rong, Jianguo Xu, Qingping Hu* \\ College of Life Sciences, Shanxi Normal University, Linfen, China \\ Email: *hqp72@163.com
}

How to cite this paper: Liu, R.Q., Wen, C.F., Zhao, Z.F., Rong, G., Xu, J.G. and Hu, Q.P. (2016) Enhancing the $\mathrm{NaCl}$ Tolerance Potential of Wheat on Root Morphology and Osmoregulation Substance by Exogenous Application of Bacillus subtilis QM3. Open Access Library Journal, 3: e3072. http://dx.doi.org/10.4236/oalib.1103072

Received: October 19, 2016

Accepted: November 10, 2016

Published: November 14, 2016

Copyright $\odot 2016$ by authors and Open Access Library Inc.

This work is licensed under the Creative Commons Attribution International License (CC BY 4.0).

http://creativecommons.org/licenses/by/4.0/

\section{c) (i) Open Access}

\begin{abstract}
Bacillus subtilis QM3 is a strain of antagonistic strains which have biological control function. Salinity is the most important limiting plant factor for agriculture development and growth changes in wheat. The present study was carried out to test tolerance involved in salt stress alleviation in wheat (Triticum aestivum L.) through the root application of $B$. subtilis QM3. Experiment was performed after germinating for two days. Wheat root was first grown under $B$. subtilis QM3 with four levels $\left(10^{8}\right.$ $\mathrm{CFU} / \mathrm{ml}$ B. sutilis $\mathrm{QM} 3$ (M1), $10^{7} \mathrm{CFU} / \mathrm{ml}$ B. subtilis $\mathrm{QM} 3$ (M2), $10^{6} \mathrm{CFU} / \mathrm{ml}$ B. subtilis $\mathrm{QM} 3(\mathrm{M} 3)$ and $10^{5} \mathrm{CFU} / \mathrm{ml}$ B. subtilis QM3 (M4)), then poured with saline regime of $\mathrm{NaCl}$ of six concentrations $(50,100,150,200,250,300 \mathrm{mmol} / \mathrm{L})$ compared along with control. The results of present study showed that B. subtilis QM3 clearly promoted the growth of the root morphology and the content of osmoregulation substance $(p<0.05)$, and $10^{6} \mathrm{CFU} / \mathrm{ml}$ B. subtilis QM3 (M3) was found to be very effective in mitigation of $\mathrm{NaCl}$ stress by promoting the growth of the wheat root and adjusting the content of osmoregulation substance in wheat root.
\end{abstract}

\section{Subject Areas \\ Microbiology}

Keywords

B. subtilis QM3, Salinity, Osmoregulation Substance, Root Morphology, $\mathrm{NaCl}$ Stress

\section{Introduction}

Salinity is one of the major environmental challenges and it causes a substantial crop 
revenue loss [1]. At present, soils of salt affected existed mostly under arid, semiarid climate because low humidity and high temperature covered approximately 800 million hectares of world [1]. According to incomplete statistics, 20\% agriculture lands are affected by salinity at world level [2]. Growth of the crops is usually diminished due to high or fluctuating salt concentrations. Salt inclusion is one of the principal mechanisms which impair the osmotic adjustment due to accumulation of inorganic ions and particularly $\mathrm{Na}^{+}$and $\mathrm{Cl}^{-}$to the toxic levels within plants through transpiration stream. The study showed that accumulation of $\mathrm{Na}^{+}$and $\mathrm{Cl}^{-}$was increased and $\mathrm{K}^{+}$was decreased as concentration of $\mathrm{NaCl}$ was increased [3]. Generally, those plants have high affinity for $\mathrm{K}^{+}$uptake, while transporters will have low $\mathrm{Na}^{+}$uptake. Similar results had been observed in other reports [4] [5]. High concentration of $\mathrm{NaCl}$ in the soil poses osmotic stress and ionic stress, which reduce the ability of plants to absorb water and minerals [6]. Excessive accumulation of sodium $\left(\mathrm{Na}^{+}\right)$ion in the cytosol damages cell membrane, which leads to leakage of electrolytes and affects metabolic activities in cytosol.

Seedling growth of several crops was affected by a detrimental factor, which created an osmotic potential in the rhizosphere of the plant. $\mathrm{Na}^{+}$and $\mathrm{Cl}^{-}$compete with other nutrients including $\mathrm{K}^{+}$, $\mathrm{Ca}^{2+}$, and $\mathrm{NO}^{3-}$, which may cause unbalance distribution and act negatively on biophysical and metabolic processes [7]. Roots and the whole crop inhibit the absorption of water or create toxic effect due to $\mathrm{Na}^{+}$and $\mathrm{Cl}^{-}$[8]. A study conducted by Ahmad and Riffat [9] on peas showed that all these changes were associated with reduction in relative water contents and $\mathrm{K}^{+}$uptake. According to this study, proline and sugar contents were significantly increased while nitrate reductase activity and chlorophyll contents were decreased.

Wheat is the third largest crop products and occupies an important position in the globe. A world population growing in number will require more grain each year. However, the salinization of the soil and other abiotic factors severely restrict the enhancement of wheat production. So, it is necessary to find methods to improve the ability of wheat to tolerate salinity. It is well known that root is the most important part of cereal, which not only can support fixation plant, but also can absorb and store salinity in the soil. Therefore, the study of plant root system has important significance on effects of salinity in soil.

In the recent past, many researchers have focused on the performance of plant growth promoting rhizobacter. A few studies have focused on alleviation of salt stress of plant, while the studies on the mitigate effect of bacteria on plant growth under salt stress are limited. Bacillus subtilis, a prokaryotic life form all around the world, is a big family that exhibits adaptation to include high salinity, drought, high and low temperatures and contaminated soils. B. subtilis QM3, a strain of antagonistic strains, has biological adjustment and control functions and is isolated from dung of Qinghai yak. Some studies have showed that B. subtilis QM3 improved germination rate of wheat seed and eased heavy metal stress of wheat seeding. So it is necessary to probe whether B. subtilis QM3 can mitigate inhibition of wheat root growth under salinity stress. 
The present investigation intends to study the influence of $B$. subtilis QM3 on morphology and metabolites (total soluble sugar, soluble proteins, proline and malon dialdehyde) of wheat root growing under different concentrations of salinity stress. The research results will provide some theoretical and practical bases to increase crop production in salt lick.

\section{Materials and Methods}

\subsection{Plant Material and Bacterial Suspension Preparati}

Seeds were purchased from the Research Institute of wheat in Shanxi Province of china B.subtilis strains QM3 were isolated from Shanxi normal university, college of life science microbiology laboratory. These strains were inoculated in a flask of $250 \mathrm{~mL}$ volume containing nutrient broth media (NB) and vigorous shaking $(200 \mathrm{rpm})$ at $37^{\circ} \mathrm{C}$ three to four days. These cultures were centrifuged $4000 \mathrm{rpm}$ for 10 minutes at $20^{\circ} \mathrm{C}$ each time, then refuse to go to clear liquid. This process was repeated use of sterile water three times. Finally these bacterial suspension liquid diluted to until the $\mathrm{OD}_{600 \mathrm{~nm}}$ in 0.8 to $0.9\left(10^{8} \mathrm{CFU} / \mathrm{ml}\right.$ B. subtilis QM3). Followed, $10^{8} \mathrm{CFU} / \mathrm{ml}$ B. subtilis QM3 which bacterial suspension liquid was diluted 10 times $\left(10^{7} \mathrm{CFU} / \mathrm{ml}\right.$ B. subtilis QM3), 100 times $\left(10^{6} \mathrm{CFU} / \mathrm{ml}\right.$ B. subtilis QM3) and 1000 times $\left(10^{5} \mathrm{CFU} / \mathrm{ml}\right.$ B. subtilis $\left.\mathrm{QM} 3\right)$ to reserve.

\subsection{Wheat Germination, Bacterium Suspension Treatment and $\mathrm{NaCl}$ Stress Treatment}

Seeds were selected to uniform, sterilized of $0.1 \% \mathrm{HgCl}$ for 10 minutes then rinsed three times with sterile water and placed onto meter glass soaked in sterile water for $24 \mathrm{~h}$. Then seeds were divided into five large groups germination of two days, each large group was placed in 7 petri dishes, five large groups respectively cultivated with sterile water (CK), $10^{8} \mathrm{CFU} / \mathrm{ml}$ B. subtilis QM3 (M1), $10^{7} \mathrm{CFU} / \mathrm{ml}$ B. subtilis QM3 (M2), $10^{6}$ $\mathrm{CFU} / \mathrm{ml}$ B. subtilis QM3 (M3) and $10^{5} \mathrm{CFU} / \mathrm{ml}$ B. subtilis QM3 (M4) for 2 days. Then exogenous application of $\mathrm{NaCl}$ with seven doses (50, 100, 150, 200, 250 and 300 $\mathrm{mmol} / \mathrm{L})$ were applied along with control. After three days', root morphological indexes were measured and osmoregulation substance content were evaluated. In total, the seedlings were grown in a constant temperature light incubator $\left(25^{\circ} \mathrm{C} ; 14 \mathrm{~h} / 10 \mathrm{~h}\right.$ light/ dark period; and 55\% relative humidity). There were three replications for each treatment.

\subsection{Root Growth Analysis}

Plants were harvested at day 7 and were divided into shoots and roots. Each gradient randomly selected three uniform roots to determine the root morphology index using the Win-RHIZO system [10]. There were three replications for each treatment.

\subsection{Physiological Attributes}

\subsubsection{Soluble Total Sugar Content Assay}

Total soluble carbohydrates were measured by anthrone colorimetry [11]. $0.1 \mathrm{~g}$ fresh 
roots were cut up into $20 \mathrm{ml}$ calibration tubes with $10 \mathrm{ml}$ distilled water, which were liable to boil over about $30 \mathrm{~min}$. The supernatant was filtrated to a volume of $20 \mathrm{ml}$ calibration tube. There were three replications for extraction. Soluble total sugar were analyzed by reacting of $0.5 \mathrm{ml}$ of sample extraction buffer with $1.5 \mathrm{ml}$ distilled water, $7.0 \mathrm{ml}$ freshly prepared anthrone $\left(1 \mathrm{~g}\right.$ anthrone $+50 \mathrm{ml}$ ethyl acetate $\left.+98 \% \mathrm{H}_{2} \mathrm{SO}_{4}\right)$ which were incubated one minutes in boiling water bath. Then determination of the samples of natural cooled at $630 \mathrm{~nm}$.

\subsubsection{Soluble Total Protein Content Assay}

Total protein concentration of the supernatant was determined according to the method described by [12] with bovine serum albumin as a standard. An amount of $2 \mathrm{gm}$ of samples were grinded in mortar with $5 \mathrm{ml}$ of phosphate buffer ( $\mathrm{pH} \mathrm{7.6)}$ and was then transformed to the centrifuge tubes. The homogenate was centrifuged at $8000 \mathrm{rpm}$ for 20 minutes. The supernatant of different samples were made equal by adding phosphate buffer solution. After extraction, $30 \mu \mathrm{l}$ of different samples were mixed with $70 \mu \mathrm{l}$ of distilled water separately. In all of these separate sample tubes $2.9 \mathrm{ml}$ of Coomassie Brilliant Blue solution was then added and mixed thoroughly. The Total volume now was $3 \mathrm{ml}$ in each tube. All these tubes were incubated for 5 minutes at room temperature and absorbance at $600 \mathrm{~nm}$ was recorded against the reagent blank. A standard curve of Absorbance (600 $\mathrm{nm}$ ) versus Concentration ( $\mu \mathrm{g})$ of protein was calculated.

\subsubsection{The Content of Proline}

Proline was assayed according to sulfosalicylic acid colorimetry [13]. $0.25 \mathrm{~g}$ fresh roots were put into large test tubes with $10 \mathrm{ml} \mathrm{30 \%} \mathrm{sulfosalicylic} \mathrm{acid,} \mathrm{which} \mathrm{was} \mathrm{liable} \mathrm{to} \mathrm{boil}$ over about $10 \mathrm{~min}$. Supernatants were filtrated to clean the tubes. Proline were measured that $2 \mathrm{ml}$ of proline extraction buffer, $4.0 \mathrm{ml}$ reaction liquid $(2 \mathrm{ml}$ of acid ninhydrin $+2 \mathrm{ml}$ of glacial acetic acid) and which were stayed 30 minutes in boiling water bath. The reaction was stopped by placing test tubes in an ice water bath and then mixing vigorously with toluene. The chromophore containing toluene was separated and absorbance read at $520 \mathrm{~nm}$ using toluene as a blank.

\subsubsection{The Content of MDA}

The content of MDA was measured by thiobarbituric acid colorimetry [14] [15].

\subsection{Statistical Analysis}

The obtained results were analyzed statistically by SPSS (version 17.0) statistical software. Data were analyzed by the analysis of variance (ANOVA) and treatment mean comparison by using least significance difference (LSD; $P=0.05$ ). Values were expressed as means \pm standard deviation $(\mathrm{SD})$.

\section{Results}

\subsection{B. subtilis QM3 Inoculation Effect on Wheat Root Morphology under NaCl Stress}

The data collected on wheat root growth (Table 1), showed that B. subtilis QM3 (M1, 
Table 1. Effects of B. subtilis QM3 on the growth of root under $\mathrm{NaCl}$ stress.

\begin{tabular}{|c|c|c|c|c|c|}
\hline $\begin{array}{c}\mathrm{NaCl} \\
\text { concentration }(\mathrm{mmol} / \mathrm{L})\end{array}$ & Treatment & Len $(\mathrm{cm})$ & $\mathrm{SA}\left(\mathrm{cm}^{2}\right)$ & $\mathrm{PA}\left(\mathrm{cm}^{2}\right)$ & $\operatorname{Vol}\left(\mathrm{cm}^{3}\right)$ \\
\hline \multirow{5}{*}{0} & CK1 & $10.16 \pm 0.16 c$ & $62.81 \pm 0.78 \mathrm{~d}$ & $19.44 \pm 0.57 \mathrm{~d}$ & $39.45 \pm 0.78 \mathrm{~d}$ \\
\hline & M1 & $10.60 \pm 0.06 \mathrm{c}$ & $67.45 \pm 0.49 c$ & $21.44 \pm 0.09 c$ & $42.59 \pm 1.87 c$ \\
\hline & M2 & $15.39 \pm 0.61 \mathrm{a}$ & $106.35 \pm 1.03 \mathrm{a}$ & $33.86 \pm 0.21 \mathrm{a}$ & $67.64 \pm 0.84 \mathrm{a}$ \\
\hline & M3 & $13.54 \pm 0.33 b$ & $86.44 \pm 1.9 \mathrm{~b}$ & $26.36 \pm 0.25 b$ & $58.59 \pm 0.94 b$ \\
\hline & M4 & $11.94 \pm 0.08 \mathrm{~b}$ & $67.72 \pm 0.33 c$ & $21.75 \pm 0.09 c$ & $43.30 \pm 2.16 \mathrm{c}$ \\
\hline \multirow{5}{*}{50} & CK2 & $10.51 \pm 0.38 \mathrm{~d}$ & $66.66 \pm 0.30 \mathrm{e}$ & $20.35 \pm 0.27 \mathrm{e}$ & $42.38 \pm 0.45 \mathrm{~d}$ \\
\hline & M1 & $11.59 \pm 0.11 \mathrm{c}$ & $71.62 \pm 0.50 \mathrm{~d}$ & $22.62 \pm 0.26 \mathrm{~d}$ & $44.54 \pm 0.87 c$ \\
\hline & M2 & $13.59 \pm 0.32 \mathrm{a}$ & $90.36 \pm 0.33 \mathrm{a}$ & $28.93 \pm 0.17 \mathrm{a}$ & $57.55 \pm 0.28 \mathrm{a}$ \\
\hline & M3 & $12.63 \pm 0.25 b$ & $75.71 \pm 0.32 \mathrm{~b}$ & $24.70 \pm 0.19 b$ & $48.39 \pm 0.61 b$ \\
\hline & M4 & $10.50 \pm 0.14 c$ & $74.61 \pm 0.23 c$ & $23.40 \pm 0.13 c$ & $45.44 \pm 1.36 \mathrm{c}$ \\
\hline \multirow{5}{*}{100} & CK3 & $7.96 \pm 0.08 c$ & $52.73 \pm 0.20 \mathrm{e}$ & $16.33 \pm 0.20 c$ & $31.42 \pm 1.95 \mathrm{~d}$ \\
\hline & M1 & $7.75 \pm 0.12 c$ & $60.54 \pm 0.10 c$ & $17.54 \pm 0.66 \mathrm{bc}$ & $33.67 \pm 0.31 \mathrm{c}$ \\
\hline & M2 & $8.56 \pm 0.35 b$ & $62.38 \pm 0.26 b$ & $18.48 \pm 0.80 \mathrm{~b}$ & $38.34 \pm 1.56 b$ \\
\hline & M3 & $9.94 \pm 0.07 \mathrm{a}$ & $66.72 \pm 0.16 \mathrm{a}$ & $20.21 \pm 0.66 \mathrm{a}$ & $40.69 \pm 0.33 \mathrm{a}$ \\
\hline & M4 & $7.94 \pm 0.08 c$ & $59.51 \pm 0.22 \mathrm{~d}$ & $17.09 \pm 0.72 c$ & $34.48 \pm 1.03 c$ \\
\hline \multirow{5}{*}{150} & CK4 & $6.51 \pm 0.24 \mathrm{c}$ & $36.41 \pm 0.32 \mathrm{e}$ & $11.05 \pm 0.80 \mathrm{c}$ & $21.47 \pm 0.69 \mathrm{~d}$ \\
\hline & M1 & $6.53 \pm 0.45 c$ & $42.48 \pm 0.17 \mathrm{c}$ & $13.98 \pm 0.75 b$ & $25.28 \pm 0.52 c$ \\
\hline & M2 & $7.52 \pm 0.28 b$ & $52.60 \pm 0.23 \mathrm{~b}$ & $15.40 \pm 1.72 \mathrm{~b}$ & $30.47 \pm 0.34 b$ \\
\hline & M3 & $8.74 \pm 0.16 \mathrm{a}$ & $59.57 \pm 0.25 \mathrm{a}$ & $17.74 \pm 0.43 \mathrm{a}$ & $33.55 \pm 0.84 a$ \\
\hline & M4 & $6.72 \pm 0.44 c$ & $39.30 \pm 0.16 \mathrm{~d}$ & $11.77 \pm 0.31 \mathrm{c}$ & $22.45 \pm 0.38 \mathrm{~d}$ \\
\hline \multirow{5}{*}{200} & CK5 & $5.02 \pm 0.16 b$ & $26.94 \pm 0.15 \mathrm{~d}$ & $8.79 \pm 0.85 b$ & $15.89 \pm 0.19 \mathrm{~d}$ \\
\hline & M1 & $5.64 \pm 0.10 \mathrm{~b}$ & $31.42 \pm 0.33 c$ & $9.72 \pm 0.69 \mathrm{~b}$ & $17.65 \pm 0.76 \mathrm{c}$ \\
\hline & M2 & $6.35 \pm 0.32 \mathrm{a}$ & $37.77 \pm 0.16 b$ & $11.81 \pm 0.18 \mathrm{a}$ & $24.65 \pm 0.32 \mathrm{~b}$ \\
\hline & M3 & $6.90 \pm 0.29 \mathrm{a}$ & $43.67 \pm 0.40 \mathrm{a}$ & $13.41 \pm 1.03 \mathrm{a}$ & $27.87 \pm 0.14 \mathrm{a}$ \\
\hline & M4 & $5.47 \pm 0.48 \mathrm{~b}$ & $26.72 \pm 0.18 \mathrm{~d}$ & $8.86 \pm 1.40 \mathrm{~b}$ & $15.01 \pm 0.59 \mathrm{e}$ \\
\hline \multirow{5}{*}{250} & CK6 & $3.82 \pm 0.77 c$ & $16.23 \pm 0.40 \mathrm{~b}$ & $5.11 \pm 0.11 \mathrm{c}$ & $7.59 \pm 0.31 \mathrm{c}$ \\
\hline & M1 & $3.75 \pm 0.46 c$ & $16.69 \pm 0.39 \mathrm{~b}$ & $5.53 \pm 0.40 \mathrm{bc}$ & $7.60 \pm 0.34 \mathrm{c}$ \\
\hline & M2 & $4.94 \pm 0.07 \mathrm{~b}$ & $17.47 \pm 1.06 \mathrm{~b}$ & $6.55 \pm 0.72 b$ & $9.56 \pm 1.04 b$ \\
\hline & M3 & $5.80 \pm 0.16 \mathrm{a}$ & $19.42 \pm 0.96 \mathrm{a}$ & $7.74 \pm 1.11 \mathrm{a}$ & $11.41 \pm 0.78 \mathrm{a}$ \\
\hline & M4 & $4.50 \pm 0.09 \mathrm{bc}$ & $17.22 \pm 0.37 \mathrm{~b}$ & $5.73 \pm 0.26 \mathrm{bc}$ & $6.61 \pm 0.57 c$ \\
\hline \multirow{5}{*}{300} & CK7 & $2.83 \pm 0.16 \mathrm{~b}$ & $11.21 \pm 0.61 \mathrm{~b}$ & $3.81 \pm 0.88 \mathrm{ab}$ & $4.59 \pm 0.31 \mathrm{ab}$ \\
\hline & M1 & $1.64 \pm 0.37 c$ & $9.60 \pm 0.11 c$ & $2.56 \pm 0.76 \mathrm{~b}$ & $2.61 \pm 0.38 c$ \\
\hline & M2 & $2.53 \pm 0.41 b$ & $10.70 \pm 0.32 \mathrm{~b}$ & $3.14 \pm 0.30 \mathrm{ab}$ & $3.82 \pm 0.29 b$ \\
\hline & M3 & $2.97 \pm 0.19 \mathrm{ab}$ & $10.72 \pm 0.33 \mathrm{~b}$ & $3.58 \pm 0.41 \mathrm{ab}$ & $4.39 \pm 0.59 \mathrm{ab}$ \\
\hline & M4 & $3.46 \pm 0.30 \mathrm{a}$ & $12.36 \pm 0.13 \mathrm{a}$ & $4.18 \pm 0.95 \mathrm{a}$ & $5.18 \pm 0.55 \mathrm{a}$ \\
\hline
\end{tabular}

$\mathrm{CK}, \mathrm{M} 1, \mathrm{M} 2, \mathrm{M} 3$ and M4 respectively represent the control group (treated with sterile water), $10^{8} \mathrm{CFU} / \mathrm{ml}$ B. subtilis QM3 (M1), $10^{7} \mathrm{CFU} / \mathrm{ml}$ B. subtilis QM3 (M2), $10^{6} \mathrm{CFU} / \mathrm{ml}$ B. subtilis $\mathrm{QM} 3$ (M3) and $10^{5} \mathrm{CFU} / \mathrm{ml}$ B. subtilis $\mathrm{QM} 3$ (M4). Len, SA, PA and Vol in the table respectively represent the root length, the root surface area, the root projection area and the root volume. Values in the table are given as mean \pm SD for 3 replicates. Different letters in the same column mean significant difference among treatments at $0.05(p<0.05)$. 
M2, M3, M4) significantly increased wheat root growth as compared to control group (CK) at all $\mathrm{NaCl}(50,100,150,200$ and $250 \mathrm{mmol} / \mathrm{L})$ levels, but at the $\mathrm{NaCl}$ concentration was $300 \mathrm{mmol} / \mathrm{L}$, Compared with control group (CK7), M3 and M4 increased, M1 and M2 decreased wheat root growth. When without $\mathrm{NaCl}$ stress, even $\mathrm{NaCl}$ concentration was $0 \mathrm{mmol} / \mathrm{L}, \mathrm{M} 1, \mathrm{M} 2, \mathrm{M} 3$ and $\mathrm{M} 4$ treatments compared with $\mathrm{CK} 1$, root length (Len), showed a obviously increase of $4.33 \%, 51.48 \%, 33.27 \%$ and $17.52 \%$; surface area (SA), showed a respectively increase of $7.39 \%, 69.32 \%, 37.62 \%$ and $7.82 \%$; projection area (PA), showed a respectively increase of $10.29 \%, 74.18 \%, 35.6 \%$ and $11.88 \%$; volume ( $\mathrm{Vol}$ ), showed a respectively increase of $7.96 \%, 71.46 \%, 48.52 \%$, and 9.76\%. When without B. subtilis QM3 treatment, even, $\mathrm{NaCl}$ concentration were 50, $100,150,200,250$ and $300 \mathrm{mmol} / \mathrm{L}$, wheat root growth were increased and then decreased. Under the $\mathrm{NaCl}$ concentration was $50 \mathrm{mmol} / \mathrm{L}$, wheat root growth reached the maximum, CK2, M1, M2, M3 and M4 compared with CK1, root length (Len), showed a obviously increase of $3.44 \%, 14.07 \%, 33.76 \%, 24.31 \%$ and $3.35 \%$; surface area (SA), showed a obviously increase of $6.13 \%, 14.03 \%, 45.32 \%, 21.76 \%$ and $19.99 \%$; projection area (PA), showed a obviously increase of 4.68\%, 16.36\%, 48.82\%, 27.06\% and 20.37\%; volume (Vol), showed a obviously increase of $2.39 \%, 12.90 \%, 45.88 \%, 22.66 \%$ and $15.18 \%$. The above data shows, when $\mathrm{NaCl}$ concentration were 0 and $50 \mathrm{mmol} / \mathrm{L}, \mathrm{M} 1$, M2, M3, and M4 was higher than that of CK, and M2 treatment was most significant than any other treatments. However, when $\mathrm{NaCl}$ concentration were 100, 150, 200 and $250 \mathrm{mmol} / \mathrm{L}, \mathrm{M} 1, \mathrm{M} 2$, M3, and M4 were higher than that of CK, M3 treatment was most significant than any other treatments. So, When $\mathrm{NaCl}$ concentration were 50,100 , 150, 200, 250 and $300 \mathrm{mmol} / \mathrm{L}$, not all concentrations of the B. subtilis QM3 bacteria liquid have a role in remission, and between different $\mathrm{NaCl}$ concentration stress, the effect of the same concentration of $B$. subtilis QM3 is different. In a certain degree, $B$. subtilis QM3 had an alleviation effect on the growth of the wheat root under $\mathrm{NaCl}$ stress.

\subsection{B. subtilis QM3 Inoculation Effect on Wheat Root Soluble Sugar Content under $\mathrm{NaCl}$ Stress}

$\mathrm{NaCl}$ treatment caused soluble sugar content of $\mathrm{M} 1, \mathrm{M} 2, \mathrm{M} 3$ and $\mathrm{M} 4$ treatments for wheat root and the $\mathrm{CK}$ showed a tendency that soluble sugar content were gradually increased with the increase of $\mathrm{NaCl}$ concentration (Figure 1). Under the $\mathrm{NaCl}$ concentration were 50,100,150, 200 and $250 \mathrm{mmol} / \mathrm{L}$, the content of soluble sugar of M1, M2, M3 and M4 treatment were higher than that of CK, M3 treatment was enhanced significantly as compared with any other treatments. However, when the $\mathrm{NaCl}$ concentration were $300 \mathrm{mmol} / \mathrm{L}$, the content of MDA of wheat root of M2, M3 and M4 treatment were higher than that of CK, M1 treatment the content of soluble sugar was lowest. Among all the $\mathrm{NaCl}$ treatment, the higher the salt concentration, the better $B$. subtilis QM3 ease the results. At the $\mathrm{NaCl}$ concentration was $0 \mathrm{mmol} / \mathrm{L}, \mathrm{M} 1, \mathrm{M} 2, \mathrm{M} 3$ and $\mathrm{M} 4$ treatment were higher than CK, M2 treatment was enhanced significantly as compared with any other treatments. 


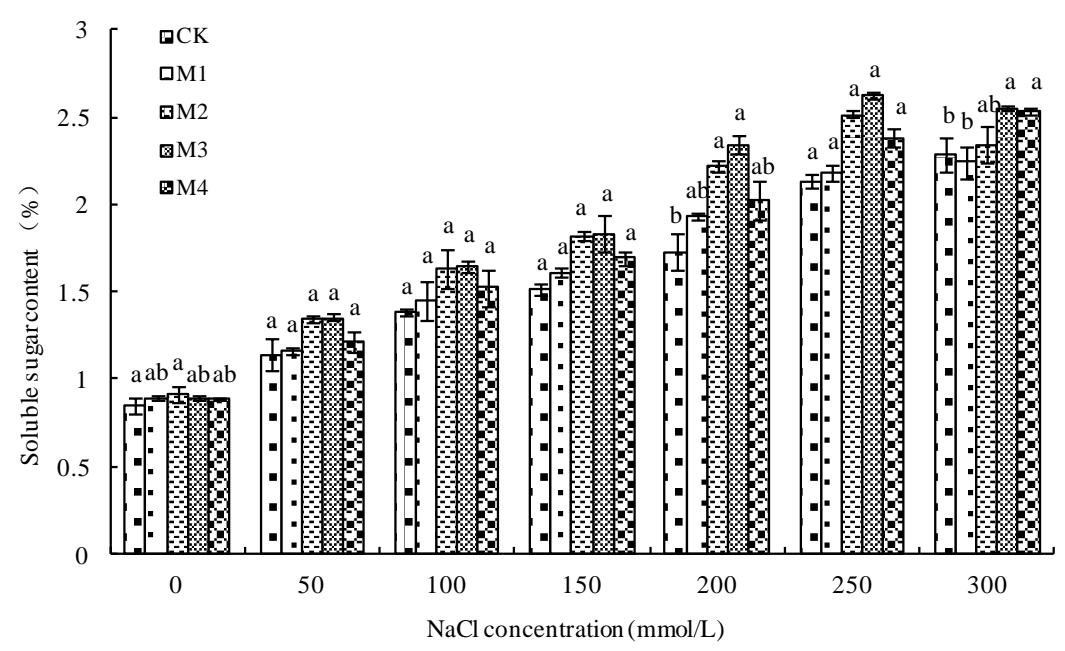

Figure 1. Effects of B. subtilis QM3 on content of soluble total sugar of wheat root under different $\mathrm{NaCl}$ stress. Values represent means of three independent replicates $\pm \mathrm{SD}$. CK, M1, M2, M3 and M4 respectively represent the control group (treated with sterile water), $10^{8} \mathrm{CFU} / \mathrm{ml}$ B. subtilis QM3 (M1), $10^{7} \mathrm{CFU} / \mathrm{ml}$ B. subtilis QM3 (M2), $10^{6} \mathrm{CFU} / \mathrm{ml}$ B. subtilis QM3 (M3) and $10^{5}$ $\mathrm{CFU} / \mathrm{ml}$ B. subtilis QM3 (M4). Different letters within a column mean statistically significant differences between the means $(p<0.05)$.

\subsection{B.subtilis QM3 Inoculation Effect on Wheat Root Total Protein Content under NaCl Stress}

With the increasing of $\mathrm{NaCl}$ concentration, the results showed that change of soluble protein content were increased after decreased in wheat root (Figure 2). Under the $\mathrm{NaCl}$ concentration was $150 \mathrm{mmol} / \mathrm{L}$, wheat root soluble protein content reached the maximum. when without $\mathrm{NaCl}$ stress, B. subtilis QM3 had an obvious promotion to soluble protein content, compared with CK1, M1, M2, M3 and M4 respectively increased by $3.98 \%, 10.45 \%, 4.13 \%$ and $6.10 \%$. Under $\mathrm{NaCl}$ concentrations were 200 $\mathrm{mmol} / \mathrm{L}, 250 \mathrm{mmol} / \mathrm{L}, 300 \mathrm{mmol} / \mathrm{L}$, soluble protein content of wheat root under the treatment of M1, M2, M3 and M4 were higher than that of CK, while under the $\mathrm{NaCl}$ concentrations were $50 \mathrm{mmol} / \mathrm{L}$ and $100 \mathrm{mmol} / \mathrm{L}$, soluble protein content of wheat root under the treatment of M1, M2 and M3 were higher than that of CK and M4, while soluble protein content of $\mathrm{M} 4$ treatment was the lowest. When $\mathrm{NaCl}$ concentration was $150 \mathrm{mmol} / \mathrm{L}$, there was no difference between CK, M1, M2 and M3, while soluble protein content of $\mathrm{M} 4$ treatment was the highest. In the $\mathrm{NaCl}$ solution concentrations were $0 \mathrm{mmol} / \mathrm{L}, 200 \mathrm{mmol} / \mathrm{L}, 250 \mathrm{mmol} / \mathrm{L}$ and $300 \mathrm{mmol} / \mathrm{L}$, soluble protein content of $B$. subtilis $\mathrm{QM} 3$ treatment was enhanced obviously than $\mathrm{CK}$. While the $\mathrm{NaCl}$ concentration were $50 \mathrm{mmol} / \mathrm{L}, 100 \mathrm{mmol} / \mathrm{L}$, Some of the concentration of B. subtilis QM3 treatment was enhanced than $\mathrm{CK}$, and $150 \mathrm{mmol} / \mathrm{L}$ among different treatments there was a slight change in the soluble protein content.

\subsection{B.subtilis QM3 Inoculation Effect on Wheat Root Proline Content under $\mathrm{NaCl}$ Stress}

Without B. subtilis QM3 treatment, the results exhibit that the content of proline were 


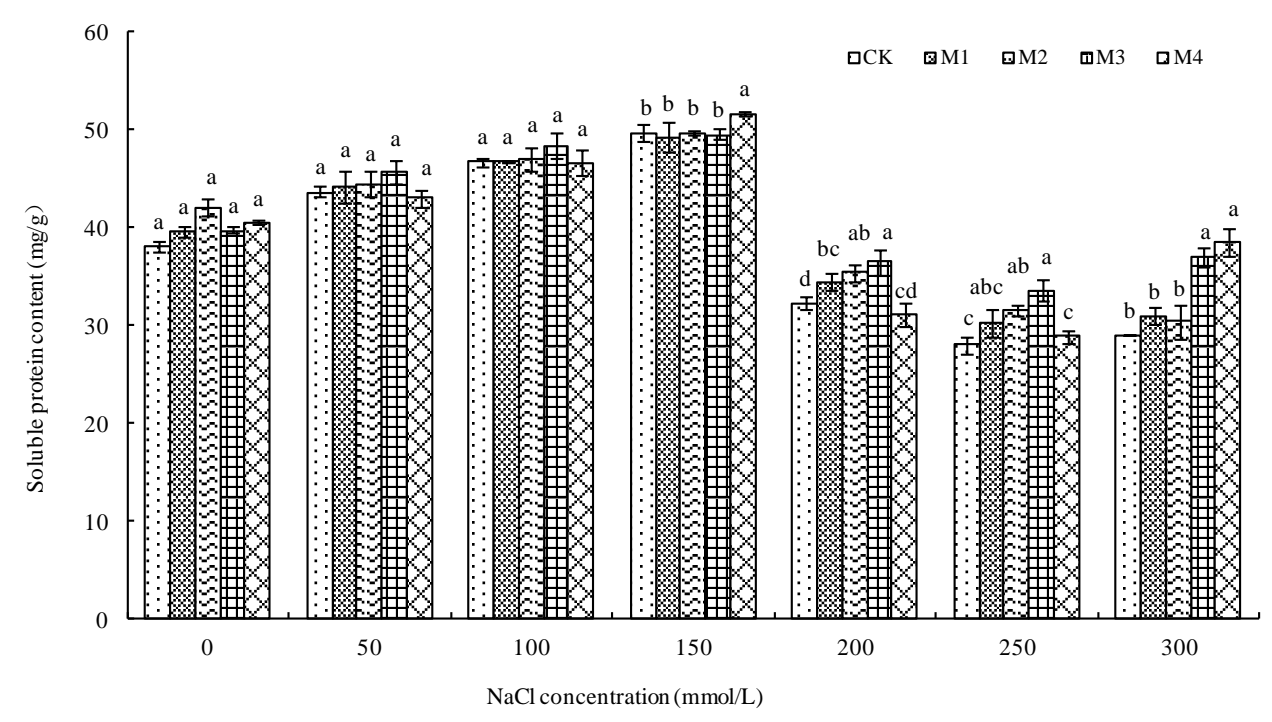

Figure 2. Effects of $B$. subtilis QM3 on content of total protein of wheat root under different $\mathrm{NaCl}$ stress. CK, M1, M2, M3 and M4 respectively represent the control group (treated with sterile water), $10^{8} \mathrm{CFU} / \mathrm{ml}$ B. subtilis QM3 (M1), $10^{7} \mathrm{CFU} / \mathrm{ml}$ B. subtilis QM3 (M2), $10^{6} \mathrm{CFU} / \mathrm{ml} B$. subtilis QM3 (M3) and $10^{5} \mathrm{CFU} / \mathrm{ml}$ B. subtilis QM3 (M4). Values in the chart are given as mean $\pm \mathrm{SD}$ for 3 replicates. Different letters in the same $\mathrm{NaCl}$ concentration column mean significant difference among treatments $(p<0.05)$.

increased under the increasing of $\mathrm{NaCl}$ concentration, under $300 \mathrm{mmol} / \mathrm{L} \mathrm{NaCl}$ concentration which reached the maximum (Figure 3). Under the different concentrations of $\mathrm{NaCl}$ stress, a certain concentration of $B$. subtilis QM3 treatment significantly decreased the content of proline. On the whole, the content of proline of wheat root under the $\mathrm{NaCl}$ treatment of M1, M2 and M3 were lower than that of CK and M4, However, when $\mathrm{NaCl}$ concentrations were $0 \mathrm{mmol} / \mathrm{l}$ and $50 \mathrm{~mol} / \mathrm{L}, \mathrm{M} 1$ treatment was reduced obviously than any other treatment, and when $\mathrm{NaCl}$ concentrations were $100 \mathrm{mmol} / \mathrm{l}$, $150 \mathrm{mmol} / \mathrm{L}, 200 \mathrm{mmol} / \mathrm{L}, 250 \mathrm{mmol} / \mathrm{L}$ and $300 \mathrm{mmol} / \mathrm{L}, \mathrm{M} 3$ treatment was the lowest at all. In all treatment groups, compared with $\mathrm{CK}$, the M4 treatment almost didn't have any relief effect.

\subsection{B.subtilis QM3 Inoculation Effect on Wheat Root MDA Content under NaCl Stress}

With the increasing of $\mathrm{NaCl}$ concentration, the content of MDA of wheat root of $\mathrm{M} 1$, M2, M3 and M4 treatments for wheat root and CK showed a tendency that the content of MDA were increased in $\mathrm{NaCl}$ treatment levels(Figure 4). Under the $\mathrm{NaCl}$ concentration were 50,100, 150, 200, 250 and $300 \mathrm{mmol} / \mathrm{L}$, the content of MDA of M1, M2, M3 and M4 treatment were lower than that of CK, M3 treatment was significantly as compared with any other treatments. M1, M2, M3 and M4 respectively increased by $11.37 \%, 28.68 \% 42.36 \%$ and $8.94 \%$ when the $\mathrm{NaCl}$ concentration was $50 \mathrm{mmol} / \mathrm{L}$. Under the $\mathrm{NaCl}$ concentration was $0 \mathrm{mmol} / \mathrm{L}$, the content of MDA of wheat root, compared with CK1, M1, M2 and M4 no obvious different, M3 was the lowest. 


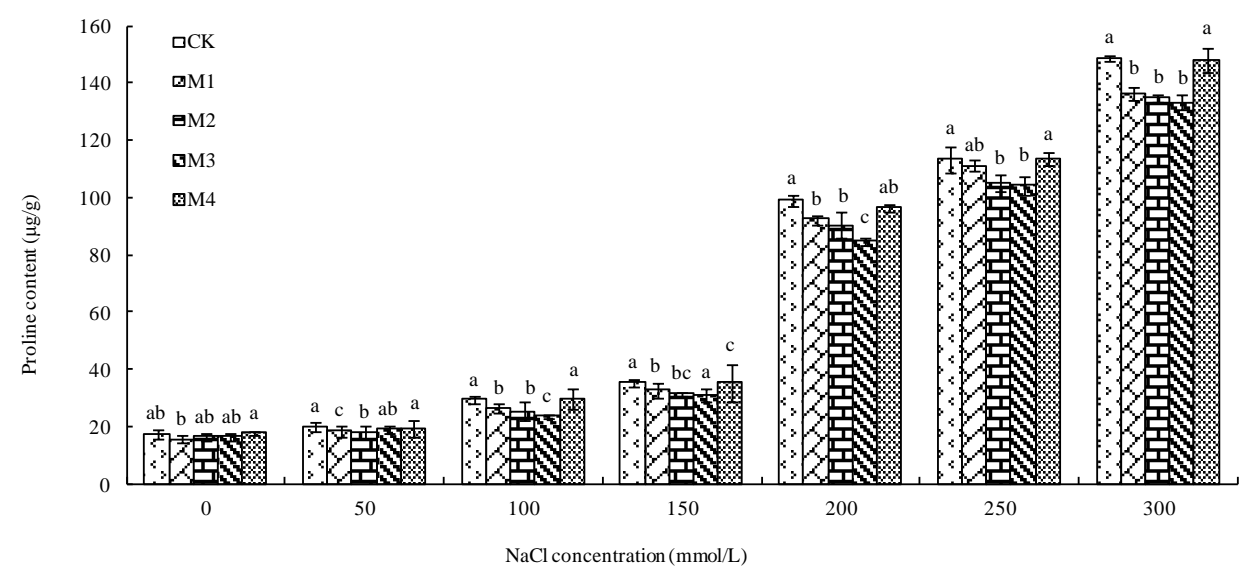

Figure 3. Effects of $B$. subtilis QM3 on content of proline of wheat root under different $\mathrm{NaCl}$ stress. CK, M1, M2, M3 and M4 respectively represent the control group (treated with sterile water), $10^{8} \mathrm{CFU} / \mathrm{ml}$ B. subtilis QM3 (M1), $10^{7} \mathrm{CFU} / \mathrm{ml}$ B. subtilis QM3 (M2), $10^{6} \mathrm{CFU} / \mathrm{ml}$ B. subtilis QM3 (M3) and $10^{5} \mathrm{CFU} / \mathrm{ml}$ B. subtilis QM3 (M4). Values in the chart are given as mean \pm SD for 3 replicates. Different letters in the same $\mathrm{NaCl}$ concentration column mean significant difference among treatments $(p<0.05)$.

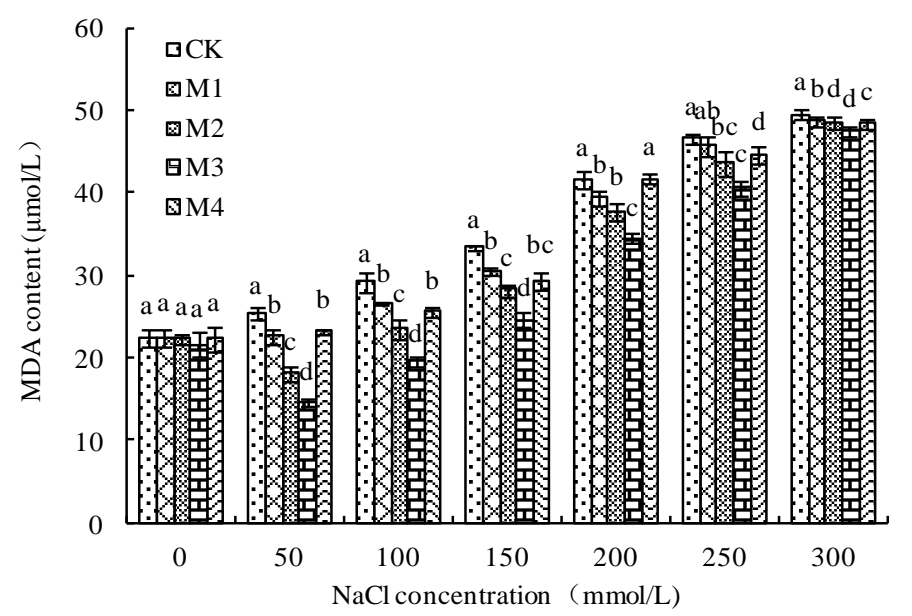

Figure 4. Effects of B. subtilis QM3 on content of MDA of wheat root under different $\mathrm{NaCl}$ stress. Values represent means of three independent replicates \pm SD. CK, M1, M2, M3 and M4 respectively represent the control group (treated with sterile water), $10^{8} \mathrm{CFU} / \mathrm{ml}$ B. subtilis QM3 (M1), $10^{7} \mathrm{CFU} / \mathrm{ml}$ B. subtilis QM3 (M2), $10^{6} \mathrm{CFU} / \mathrm{ml}$ B. subtilis QM3 (M3) and $10^{5} \mathrm{CFU} / \mathrm{ml} B$. subtilis QM3 (M4). Different letters within a column mean statistically significant differences between the means $(p<0.05)$.

\section{Discussion}

Higher $\mathrm{NaCl}$ concentration, the dominant salt in the soil, has a direct effect on plant growth, poses osmotic stress and ionic stress, which reduces the ability of plants to absorb water and minerals [6] [16].

$\mathrm{NaCl}$ stresses affect negatively first seed germination and then root length. Plant early growth stage is more sensitive as compared to later stages so inoculation with bacteria having ability to mitigate salinity stress can be helpful for plants to overcome from 
stress [17] [18] [19].

Different researchers have also reported that PGPR inoculation also improved seed genrmination under salinity stress [20] [21] [22]. $\mathrm{Na}^{+}$and $\mathrm{Cl}^{-}$are necessary to plant growth, then a number of reports have showed that high concentration of $\mathrm{NaCl}$ stress inhibit plant root and proliferation [23] [24] [25] [26]. Our result was carried out to evaluate exogenous application of Bacillus subtilis QM3 enhancing $\mathrm{NaCl}$ tolerant potential of wheat through assessing on root morphology and osmoregulation substance attributes, which showed that $\mathrm{NaCl}$ stress caused a significant inhibition on wheat root growth, including the root length, root surface area, root volume and root projection. However, under the $\mathrm{NaCl}$ concentration of $50 \mathrm{mmol} / \mathrm{L}$, the wheat root growth was promoted, it may due to the dual role of $\mathrm{NaCl}$ in plant. From other $\mathrm{NaCl}$ concentrations stress, in a certain degree, B. subtilis QM3 had an enhanced the $\mathrm{NaCl}$ tolerance potential on the growth of the wheat root.

As plant osmoregulation substances are concerned in regulating a series of physiological and biochemical processes, changes in physiological conditions like proline, protein and carbohydrate [27], biosynthesis the analysis of the role of new plant growth regulators in crop abiotic stress tolerance is being a great deal of focus these days [28]. It has been commonly reported that salt stress is one of the major causes of oxidative damage to plant tissues [29].

Sugars perform important regulatory functions in plants including photosynthesis [30] and carb ohydrate partitioning [31] [32]. Soluble sugar to osmotic adjustment, the increase of its concentration could increase the concentration of cell protoplasm, to maintain normal membrane function.

Excessive salt accumulation is the obvious effects on protein metabolism, which inhibit synthesis and promote decomposition. The inhibit protein synthesis directly causes may be the synthesis of amino acids.

The accumulation of amino acids was involved in osmotic adjustment, free radical scavenging, maintenance of protein and membrane integrity [33]. A number of reports have showed the amount of the content of proline increased significantly and gradually with increasing $\mathrm{NaCl}$ concentration. Proline serves as an important compatible osmolyte, and its accumulation is believed to reduce cellular water potential and avoid deleterious toxicity of high ionic strength, has also been proposed to serve as reactive oxygen species scavenger [34] and its accumulation can stabilize the structure of membranes and proteins to minimize the damage of cells under salt stress.

It was reported that MDA content on different plant species increased significantly with the processing salt level rising [35] [36]. These increases may be attributed to that salinity could modify the membrane structure and stimulate $\mathrm{O}_{2}$ production, which facilitates lipid peroxidation [37].

Study found that the content of soluble sugar, proline and MDA increased in $\mathrm{NaCl}$ concentration level. However, the content of soluble protein increased in low $\mathrm{NaCl}$ level (50, 100, 150 and $200 \mathrm{mmol} / \mathrm{L})$, decreased in high $\mathrm{NaCl}$ concetration level (200, 250 and $300 \mathrm{mmol} / \mathrm{L}$ ). Under the same $\mathrm{NaCl}$ concentration level, Basically, M1, M2, M3 and M4 
treatment compared with control group, under the different level can be increased or decreased osmoregulation substance to increase the osmotic regulation ability of wheat root, enhancing the $\mathrm{NaCl}$ tolerance potential on wheat root, and $\mathrm{M} 3$ treatment is most obvious effect than any other treatments.

On the whole, plant self-protection ability is limited, a certain of $\mathrm{NaCl}$ concentration stresses in wheat root, compared with the control group, the treatment of B. subtilis QM3 contributed to osmotic regulation ability of the wheat root improved to a certain degree, so as to restrain the excessive accumulation of $\mathrm{Na}^{+}$and $\mathrm{Cl}^{-}$caused permeability damage, reduce lipid peroxidation of cell membrane and maintain the relative integrity and orderliness, at last, enhanced the $\mathrm{NaCl}$ tolerance potential on the growth of the wheat root. By comparison, $10^{6} \mathrm{CFU} / \mathrm{ml}$ B. subtilis QM3 bacteria liquid treatment was enhanced obviously than any other treatments. $10^{8} \mathrm{CFU} / \mathrm{ml}$ B. subtilis QM3 and $10^{7}$ $\mathrm{CFU} / \mathrm{ml}$ B. subtilis $\mathrm{QM} 3$ has a higher concentration, and $10^{6} \mathrm{CFU} / \mathrm{ml}$ B. subtilis QM3 has a lower concentration, these two reasons may lead to their alleviate effect are not as good as $10^{6} \mathrm{CFU} / \mathrm{ml}$ B. subtilis $\mathrm{QM} 3$ solution.

\section{Conclusion}

When the plants suffer $\mathrm{NaCl}$ stress, bacterium induces the concentration of osmoregulation content to improve the penetration ability by combining with wheat roots, resulting in increased plant tolerance to $\mathrm{NaCl}$. In this study, the wheat root inoculated with $10^{6} \mathrm{CFU} / \mathrm{ml} \mathrm{B.} \mathrm{subtilis} \mathrm{QM3} \mathrm{conformed} \mathrm{better} \mathrm{effect} \mathrm{in} \mathrm{terms} \mathrm{of} \mathrm{root} \mathrm{morphology,}$ soluble sugar content, total protein content, MDA content and proline content as compared to $10^{8} \mathrm{CFU} / \mathrm{ml}$ B. subtilis $\mathrm{QM} 3,10^{7} \mathrm{CFU} / \mathrm{ml}$ B. subtilis $\mathrm{QM} 3$ and $10^{5} \mathrm{CFU} / \mathrm{ml}$ B. subtilis $\mathrm{QM} 3$. Such studies are necessary to select a suitable bacterium and an optimal concentration of a suitable bacterium to be used as bioinoculant for sustainable wheat production under saline areas.

\section{Acknowledgements}

This work was financially supported by a Project of the Natural Science Foundation of Shanxi Province, China (Project No. 201601D011070).

\section{References}

[1] Khan, A.H., Singh, A.K., Mubeen, Singh, S., Zaidi, N.W., Singh, U.S. and Haefele, S.M. (2014) Response of Salt-Tolerant Rice Varieties to Biocompost Application in Sodic Soil of Eastern Uttar Pradesh. American Journal of Plant Sciences, 5, 7-13. http://dx.doi.org/10.4236/ajps.2014.51002

[2] Yeo, A.R. (1999) Predicting the Interaction between the Effects of Salinity and Climate Change on Crop Plants. Scientia Horticulturae, 78, 159-174. http://dx.doi.org/10.1016/S0304-4238(98)00193-9

[3] Ayyub, C.M., Ali, M., Shaheen, M.R., Qadri, R.W.K., Khan, I., Jahangir, M.M., Abbasi, K.Y., Kamal, S. and Zain, M. (2015) Enhancing the Salt Tolerance Potential of Watermelon ( $C i$ trullus lanatus) by Exogenous Application of Salicylic Acid. American Journal of Plant Sciences, 6, 3267-3271. http://dx.doi.org/10.4236/ajps.2015.619318 
[4] Maathuis, F.J.M. and Amtmann, A. (1999) $\mathrm{K}^{+}$Nutrition and $\mathrm{Na}^{+}$Toxicity: The Basis of Cellular $\mathrm{K}^{+} / \mathrm{Na}^{+}$Ratios. Annals of Botany, 84, 123-133.

http://dx.doi.org/10.1006/anbo.1999.0912

[5] Cengiz, K., Tuna, A.L., Muhammad, A. and Hakan, A. (2007) Improved Salt Tolerance of Melon (Cucumis Melo L.) by Addition of Proline and Potassium Nitrate. Environmental and Experimental Botany, 60, 397-403. http://dx.doi.org/10.1016/j.envexpbot.2006.12.008

[6] Munns, R., James, R.A. and Läuchli, A. (2006) Approaches to Increasing the Salt Tolerance of Wheat and Other Cereals. Journal of Experimental Botany, 57, 1025-1043. http://dx.doi.org/10.1093/jxb/erj100

[7] Mansour, M., Salama, K. and Ali, F. (2005) Cell and Plant Responses to $\mathrm{NaCl}$ in Zea mays L. Cultivars Differing in Salt Tolerance. General and Applied Plant Physiology, 35, 29-41.

[8] Khajeh-Hosseini, M., Powell, A.A. and Bimgham, I.J. (2003) The Interaction between Salinity Stress and Seed Vigor during Germination of Soybean Seeds. Seed Science Technology, 31, 715-725. http://dx.doi.org/10.15258/sst.2003.31.3.20

[9] Ahmad, P. and Riffat, J. (2005) Effect of Salt Stress on Growth and Biochemical Parameters of pisum sativum L. Archives of Agronomy and Soil Science, 51, 665-672. http://dx.doi.org/10.1080/03650340500274151

[10] Hao, Y., Wu, H.T., Liu, Y.F. and Hu, Q.P. (2015) Mitigative Effect of Bacillus subtilis QM3 on Root Morphology and Resistance Enzyme Activity of Wheat Root under Lead Stress. Advances in Microbiology, 5, 469-478. http://dx.doi.org/10.4236/aim.2015.56048

[11] Ding, Y., Luo, W. and Xu, G. (2006) Characterization of Magnesium Nutrition and Interaction of Magnesium and Potassium in Rice. Annals of Applied Biology, 149, 111-123. http://dx.doi.org/10.1111/j.1744-7348.2006.00080.x

[12] Badford, M.M. (1976) A Rapid and Sensitive Method for the Quantitation of Microgram Quantities of Protein Utilizing the Principle of Protein Dye Binding. Analytical Biochemistry, 72, 248-254. http://dx.doi.org/10.1016/0003-2697(76)90527-3

[13] Bates, L.S., Waldren, R.P. and Reare, I.D. (1973) Rapid Determination of Free Proline for Water Stress Studies. Plant and Soil, 39, 205-207. http://dx.doi.org/10.1007/BF00018060

[14] Heath, R.L. and Packer, L. (1968) Photoperoxidation in Isolated Chloroplasts: I. Kinetics and Stoicchiometry of Fatty Acid Peroxidation. Archives of Biochemtry Biophysics, 125, 189-198. http://dx.doi.org/10.1016/0003-9861(68)90654-1

[15] Shah, K., Kumar, R.G., Verma, S. and Dubey, R.S. (2001) Effect of Cadmium on Lipid Peroxidation, Superoxide Anion Generation and Activities of Antioxidant Enzymes in Growing Rice Seedlings. Plant Science, 161, 1135-1144. http://dx.doi.org/10.1016/S0168-9452(01)00517-9

[16] Munas, R. and Testar, M. (2008) Mechanism of Salinity Tolerance. Annual Review of Plant Biology, 59, 651-681. http://dx.doi.org/10.1146/annurev.arplant.59.032607.092911

[17] Nadeem, S.M., Zahir, Z.A., Naveed, M., Asghar, H.N. and Arshad, M. (2010) Rhizobacteria Capable of Producing ACC-Deaminase May Mitigate Salt Stress in Wheat. Soil Science Society of America Journal, 74, 533-542. http://dx.doi.org/10.2136/sssaj2008.0240

[18] Foolad, M.R. (2000) Genetic Basis of Salt Tolerance and Cold Tolerance in Tomato. Current Opinion in Plant Biology, 2, 35-49.

[19] Sallam, H.A. (1999) Effect of Some Seed-Soaking Treatments on Growth and Chemical Components on Faba Bean Plants under Saline Conditions. Annals of Agricultural Sciences, 44, 159-171. 
[20] Ashraf, M., Zafar, R. and Ashraf, M.Y. (2003) Time-Course Changes in the Inorganic and Organic Components of Germinating Sunflower Achenes under Salt (NaCl) Stress. Flora, 198, 26-36. http://dx.doi.org/10.1078/0367-2530-00073

[21] Nelson, L.M. (2004) Plant Growth Promoting Rhizobacteria (PGPR): Prospects for New Inoculants. Crop Management, 10, 301-305. http://dx.doi.org/10.1094/cm-2004-0301-05-rv

[22] Barassi, C.A., Ayrault, G., Creus, C.M., Sueldo, R.J. and Sobrero, M.T. (2006) Seed Inoculation with Azospirillum mitigates $\mathrm{NaCl}$ Effects on Lettucee. Scientia Horticulturae, 109, 814. http://dx.doi.org/10.1016/j.scienta.2006.02.025

[23] Mishra, M., Kumar, U., Mishra, P.K. and Prakash, V. (2010) Efficiency of Plant Growth Promoting Rhizo-Bacteria for the Enhancement of Cicer arietinum L. Growth and Germination under Salinity. Advances in Biological Research, 4, 92-96.

[24] Ashraf, M. (1994) Breeding for Salinity Tolerance in Plants. Critical Reviews Plant Sciences, 13, 17-42. http://dx.doi.org/10.1080/713608051

[25] Marschner, H. (1988) Mineral Nutrition of Higher Plants. Journal of Ecology, 76, 681-861.

[26] Glick, B.R., Liu, C., Ghosh, S. and Dumbroff, E.B. (1997) Early Development of Canola Seedlings in the Presence of the Plant Growth-Promoting Rhizobacterium Pseudomonas putida GR12-2. Soil Biology and Biochemistry, 29, 1233-1239.

http://dx.doi.org/10.1016/S0038-0717(97)00026-6

[27] Tang, D., Shi, S., Li, D., Hu, C. and Liu, Y. (2007) Physiological and Biochemical Responses of Scytonema javanicum (Cyanobacterium) to Salt Stress. Journal of Arid Environments, 71, 312-320. http://dx.doi.org/10.1016/j.jaridenv.2007.05.004

[28] Zvi, P. and Eduardo, B. (2011) Hormone Balance and Abiotic Stress Tolerance in Crop Plants. Current Opinion in Plant Biology, 14, 290-295. http://dx.doi.org/10.1016/j.pbi.2011.02.001

[29] Sanjib, K.P., Lal, B.S. and Mohammad, H.K. (2003) Does Aluminum Phytotoxicity Induce Oxidative Stress in Green Gram (Vigna radiata)? Bulgarian Journal of Plant Physiology, 29, 77-86. https://www.researchgate.net/publication/237134047

[30] Rolland, F., Moore, B. and Sheen, J. (2002) Sugar Sensing and Signaling in Plants. Plant Cell, 14, 185-205.

[31] Tzyy-Jen, C. and Daniel, R.B. (1998) Sucrose Is a Signal Molecule in Assimilate Partitioning. Proceedings of the National Academy of Sciences of the United States of America, 95, 4784-4788. http://dx.doi.org/10.1073/pnas.95.8.4784

[32] Fred, R. and Michael, W.B. (2003) Genetic Approaches to Understanding Sugar-Response Pathways. Journal of Experimental Botany, 54, 495-501. http://dx.doi.org/10.1093/jxb/erg054

[33] Keutgen, A.J. and Pawelzik, E. (2008) Contribution of Amino Acids to Strawberry Fruit Quality and Their Relevance as Stress Indicators under NaCl Salinity. Food Chemistry, 111, 642-647. http://dx.doi.org/10.1016/j.foodchem.2008.04.032

[34] Verbruggen, N. and Hermans, C. (2008) Proline Accumulation in Plants: A Review. Amino Acids, 35, 753-759. http://dx.doi.org/10.1007/s00726-008-0061-6

[35] El-Beltagi, H.S., Salama, Z.A. and El Hariri, D.M. (2008) Some Biochemical Markers for Evaluation of Flax Cultivars under Salt Stress Conditions. Journal of Natural Fibers, 5, 316330. http://dx.doi.org/10.1080/15440470802252487

[36] Sadak, M.S., Abdelhamid, M.T. and El-Saady, M.A. (2010) Physiological Responses of Faba Bean Plant to Ascorbic Acid Grown under Salinity Stress. Egyptian Journal of Agronomy, 
32, 89-106.

[37] Zhang, J. and Kirkham, M.B. (1996) Sorghum and Sunflower Seedlings as Affected by Ascorbic Acid, Benzoic Acid and Prophyl Gallate. Journal of Plant Physiology, 149, 489-493.

http://dx.doi.org/10.1016/S0176-1617(96)80323-3

Submit or recommend next manuscript to OALib Journal and we will provide best service for you:

- Publication frequency: Monthly

- 9 subject areas of science, technology and medicine

- Fair and rigorous peer-review system

- Fast publication process

- Article promotion in various social networking sites (LinkedIn, Facebook, Twitter, etc.)

- Maximum dissemination of your research work

Submit Your Paper Online: Click Here to Submit

Or Contact service@oalib.com 